\title{
The role of the seminal vesicles, coagulating glands and prostate glands on the fertility and fecundity of mice
}

\author{
S. F. Pang, P. H. Chow* and T. M. Wong \\ Department of Physiology and ${ }^{*}$ Department of Anatomy, Faculty of Medicine, University of \\ Hong Kong, Hong Kong
}

\begin{abstract}
Summary. Female mice were allowed to mate with males which had been shamoperated (Group 1); had seminal vesicles, coagulating glands and ventral and dorsal prostate glands removed (Group 2); had the seminal vesicles removed (Group 3); had the coagulating glands removed (Group 4) or had the ventral and dorsal prostate gland removed (Group 5). The pregnancy rate was normal in Groups 1 and 4, severely reduced in Groups 2 and 3 and less so in Group 5. Litter size was reduced in Groups 2 and 3 but not in Group 5. It is suggested that the seminal vesicles and possibly the prostate glands are important in the production of young in mice.
\end{abstract}

\section{Introduction}

In the past decade, the male accessory sex organs have received much attention. Most studies have followed three directions: (1) the biochemical or structural changes of the accessory sex organs in relation to the mechanism of action of androgens (Brandes, 1974; Cavazos, 1975); (2) the aetiology of pathological conditions of the accessory sex organs (Brandes, 1974; Hafez, 1976); and (3) analyses of the composition of seminal fluid (Brandes, 1974; Eliasson \& Lindholmer, 1976). Whether and how much these accessory sex organs contribute individually to mammalian fertility, however, have received little attention.

In 1945, Blandau removed the coagulating gland and the seminal vesicle of rats and although copulation appeared normal, no young were produced. It was suggested that the formation of the vaginal plug after coitus was necessary for the opening of the cervix to allow entrance for the spermatozoa and hence fertilization of the ovum. We have conducted similar experiments with male mice to investigate the functional significance of the accessory sex organs in these animals.

\section{Materials and Methods}

Male and female albino mice, obtained from the Animal House, Faculty of Medicine, University of Hong Kong, were used. Virgin female mice, 40-45 days old and weighing $20 \pm 2 \mathrm{~g}(\mathrm{~N}=80)$ were allowed to mate with vigorous males. After 5 days, the males were removed and the females were checked regularly for young. Females of proven fertility were thus identified for subsequent experiments.

Male mice $(25 \pm 2 \mathrm{~g})$ were anaesthetized with pentobarbitone sodium $(50 \mathrm{mg} / \mathrm{kg})$. A $1 \cdot 2 \mathrm{~cm}$ incision was made on the posterior abdominal wall, $0.2 \mathrm{~cm}$ anterior to the penis. Seminal vesicles, coagulating glands and ventral and dorsal prostate glands were exposed and bilateral removal of one or all of the male accessory sex organs was effected. The prostate glands were removed under the dissecting microscope. Care was taken not to damage any other tissues. The incision was closed by sutures. The experimental groups were as follows: Group 1, shamoperated mice in which the abdomen had been opened and closed as above; Group 2, total 
bilateral removal of seminal vesicles, coagulating glands and ventral and dorsal prostate glands; Group 3, bilateral removal of seminal vesicles; Group 4, bilateral removal of coagulating glands; Group 5, bilateral removal of ventral and dorsal prostate glands. About $10 \%$ of the mice died after surgery, mainly because of problems with the anaesthesia.

At 20 days after operation, the male mice were randomly chosen and individually paired with 1 female. After 11-14 days, the male mice were killed and the condition of the relevant accessory sex glands was checked. At autopsy cannulae were inserted into the two vasa deferentia and saline was injected to test for patency. This test failed for 1 male in each of Groups 3 and 4 and data from these animals were disregarded.

The female mice were checked regularly for young, which were counted at birth and then removed. The experiment was repeated with the same females 1 week after the last female had littered. Since there was no significant difference between the results of the two experiments, the data were combined. The fertility and fecundity of the males were evaluated by $\chi^{2}$ and 2 tailed $t$ tests; a $P$ value of $<0.05$ was considered significant.

\section{Results}

These are shown in Table 1. Pregnancy was severely affected in Groups 2 and 3 and less so in Group 5. There were no differences between the average litter size of the animals in Groups 4 and 5 compared with that of the controls (Group 1), but the litters in Groups 2 and 3 were much smaller (Table 1).

Table 1. The effects of excision of all the accessory sex glands (Group 2), the seminal vesicles (Group 3), the coagulating glands (Group 4) or the ventral and dorsal lobes of the prostate gland (Group 5) on the fertility and fecundity of mice

\begin{tabular}{|c|c|c|c|c|c|}
\hline \multirow[b]{2}{*}{ Group } & \multirow[b]{2}{*}{$\begin{array}{c}\text { No. of males } \\
\text { used }\end{array}$} & \multicolumn{2}{|c|}{ No. of females } & \multicolumn{2}{|c|}{ Litters } \\
\hline & & Not pregnant & Pregnant (\%) & No.‡ & $\begin{array}{c}\text { Mean } \pm \text { s.e.m } \\
\text { size }\end{array}$ \\
\hline 1 & 60 & 16 & $44(73)$ & 43 & $9.4 \pm 0.3$ \\
\hline 2 & 16 & 14 & $2(13)^{*}$ & 2 & $6.0 \pm 1.4+$ \\
\hline 3 & 14 & 13 & $1(7)^{*}$ & 1 & $\overline{4}$ \\
\hline 4 & 22 & 6 & $16(73)$ & 4 & $9 \cdot 2 \pm 2.8$ \\
\hline 5 & 13 & 8 & $5(38)^{*}$ & 4 & $9.8 \pm 0.9$ \\
\hline
\end{tabular}

* Significantly different from the value for the sham-operated controls (Group 1), $P<0.05$ ( $\chi^{2}$ test).

$\dagger$ Significantly different $(P<0.05)$ from the value for Group 1 (2-tailed $t$ test).

$\ddagger$ Some litters were killed at birth and could not be counted.

\section{Discussion}

The lack of study of the importance of the accessory sex organs on fertility may be due to the discovery that a high rate of pregnancy was obtained in guinea-pigs after insemination with spermatozoa taken from the distal cauda epididymidis (Young, 1931). Similar results were obtained for rats (Blandau \& Rumery, 1964) and rabbits (Bedford, 1963). These observations suggest that spermatozoa from the cauda epididymidis have matured and have the full ability to fertilize the matured ovum, but do not preclude involvement of the accessory sex organs during fertilization in vivo. Blandau (1945) suggested that when the seminal vesicles and coagulating glands were removed, and no vaginal plug was formed, the cervix remained closed and spermatozoa could not travel up the female genital tract to fertilize the ovum. 
The importance of the accessory sex organs on fertility in mice was confirmed in the present study. However, although both coagulating glands and seminal vesicles are necessary for the production of a vaginal plug in rodents (Gotterer, Ginsberg, Schulman, Banks \& WilliamsAshman, 1955), the removal of the seminal vesicles had a much greater effect on fertility than did removal of the coagulating glands. Thus, the lack of formation of the vaginal plug may not be the reason for the infertility observed in the present experiments.

Removal of the ventral and dorsal prostate glands also resulted in a lower fertility rate in the mice in the present study unlike the results for rats in which no change in fertility and fecundity was observed (Gunn \& Gould, 1958).

In man the concentration of spermatozoa (Polakoski, Syner \& Zaneveld, 1976) or the volume of the ejaculate (Amelar \& Hotchkiss, 1965; Cicero et al., 1975) appear to be important in fertility. Since the secretions of the accessory sex organs are the main contribution to the volume of ejaculates, removal of the prostate glands and seminal vesicles may greatly alter the concentration of spermatozoa or the volume of ejaculate in mice and thus may account for the lower fertility observed in the mice in Groups 2,3 and 5. There are other possible explanations. Under natural conditions, to achieve successful fertilization of the matured ovum in the oviduct by mature spermatozoa from the cauda epididymidis, the following have to be accomplished: (1) a high survival rate of spermatozoa in the male reproductive tract; (2) the successful copulation of the male and the female; (3) a high survival rate of spermatozoa in the female reproductive tract, and (4) the successful transportation of spermatozoa to the ovum. Removal of the seminal vesicles and/or ventral and dorsal prostate glands may affect any one or a combination of the above processes. Blandau (1945), Beach \& Wilson (1963) and Larsson \& Swedin (1971) demonstrated that removal of the accessory sex organs did not influence the normal mating behaviour of male rats. In rats and guinea-pigs, the secretion of the prostate glands has been reported to stimulate uterine motility (Ventura \& Freund, 1970). It has also been demonstrated that secretions of the accessory sex organs play an important role in the motility and viability of the spermatozoa in man (Lindholmer, 1974; Eliasson \& Lindholmer 1976). Biochemical studies have demonstrated that, apart from furnishing an osmotically balanced milieu for the spermatozoa, the seminal plasma also contains substances such as sugars, enzymes, hormones, inorganic ions and polyamines. The function of these substances in relation to sperm transport and motility is still speculative (Price \& Williams-Ashman, 1961; Mann, 1974; Brandes, 1974; Hafez, 1976). Investigations on the biochemical nature of the secretions of individual accessory sex organs and the contribution of these substances on the survival and motility of spermatozoa or the motility of the female reproductive tract may provide information on the mechanism(s) underlying the infertility observed after removal of seminal vesicles and prostate glands in mice.

The work was supported by the Department of Physiology and Department of Anatomy, University of Hong Kong. We thank Professor A. C. L. Hsieh and Mr C. K. Leung for advice and $\mathrm{Mr} \mathrm{M}$. K. Yip, Mr A. C. Ng and Mr W. K. Ma for assistance.

\section{References}

Amelar, R.D. \& Hotchkiss, R.S. (1965) The split ejaculate-its uses in the management of male infertility. Fert. Steril. 16, 45-60.

Beach, F.A. \& Wilson, J.R. (1963) Mating behavior in male rats after removal of the seminal vesicles Proc. natn. Acad. Sci. U.S.A. 49, 624-626.

Bedford, J.M. (1963) Morphological changes in rabbit spermatozoa during passage through the epididymis. J. Reprod. Fert. 5, 169-177.
Blandau, R.J. (1945) On the factors involved in sperm transport through the cervix uteri of the albino rat. Am. J. Anat. 77, 253-272.

Blandau, R.J. \& Rumery, R.E. (1964) The relationship of swimming movements of epididymal spermatozoa to their fertilizing capacity. Fert. Steril. 15, 571-579.

Brandes, D. (1974) Male Accessory Sex Organs: Structure and Function in Mammals. Academic, New York. 
Cavazos, L.F. (1975) Fine structure and functional correlates of male accessory sex glands of rodents. In Handbook of Physiology: Vol. 5. Endocrinology, pp. 353-381. Eds D. W. Hamilton \& R. O. Greep. Am. Physiol. Soc., Washington, D.C.

Cicero, T.J., Bell, R.D., Wiest, W.G., Allison, J.H., Polakoski, K.L. \& Robins, E. (1975) Function of the male sex organs in heroin and methodone users. $N$. Engl. J. Med. 292, 882-887.

Eliasson, R. \& Lindholmer, C. (1976) Functions of male accessory genital organs. In Human Semen and Fertility Regulation in Man, pp. 44-50. Eds E.S.E. Hafez. Mosby Co., St. Louis.

Gotterer, G., Ginsberg, D., Schulman, T., Banks, J. \& Williams-Ashman, H.G. (1955) Enzymatic coagulation of semen. Nature, Lond. 176, 12091211.

Gunn, S.A. \& Gould, T.C. (1958) Role of zinc in fertility and fecundity in the rat. Am. J. Physiol. 193, 505508.

Hafez, E.S.E. (1976) Human Semen and Fertility Regulation in Men. Mosby Co., St. Louis.

Larsson, K. \& Swedin, G. (1971) The sexual behavior of male rats after bilateral section of the hypogastric nerve and removal of the accessory genital glands. Physiol. Behav. 6, 251-253.
Lindholmer, C. (1974) The importance of seminal plasma for human sperm motility. Biol. Reprod. 10, 533-542.

Mann, T. (1974) Secretory function of the prostate, seminal vesicle and other male accessory organs of reproduction. J. Reprod. Fert. 37, 179-188.

Polakoski, K.L., Syner, F.N. \& Zaneveld, L.J.D. (1976) Biochemistry of human seminal plasma. In Human Semen and Fertility Regulation in Men, pp. 133143. Ed. E. S. E. Hafez. Mosby Co., St. Louis.

Price, D. \& Williams-Ashman, H.G. (1961) The accessory reproductive glands of mammals. In Sex and Internal Secretions, 2nd edn, pp. 366-448. Ed. W. C. Young. Williams and Wilkins Co., Baltimore.

Ventura, W.P. \& Freund, M. (1970) Effects of human, rat, and guinea pig semen, and the accessory gland secretions on in vitro motility of female reproductive tract. Fedn Proc. Fedn Am. Socs exp Biol. 29, 261.

Young, W.C. (1931) A study of the function of the epididymis. III. Functional changes undergone by spermatozoa during their passage through the epididymis and vas deferens in the guinea-pig. $J$. exp. Biol. 8, 151-162.

Received 2 August 1978 